\title{
Biodiesel production from aquatic vegetation
}

\author{
Mercy Nimal Fernando and Ranganathan Kapilan \\ Department of Botany, Faculty of Science, University of Jaffna, Sri Lanka \\ Email: rkapilan@univ.jfn.ac.lk
}

\begin{abstract}
Biodiesel production from natural resources has drawn special focus due to its cost effectiveness, environmental friendliness and affordability compared to the environmentally challenging fossil fuels. The aquatic vegetation especially marine algae and weeds, is considered as the more secure, less competitive and express an exponential growth rate in their natural habit. They have the capacity to produce diverse waste supplements without much care, and most of the aquatic plants are not utilized for human food and animal feed. Biodiesel is produced by reacting lipids with alcohol that results in fatty acid esters. Transesterification and oil extraction are the two prime processes where diverse mechanical and chemical approaches involve. Transesterification reaction comprises of changing fatty oils into unsaturated fat alkyl esters, with alcohol and alkali catalyst with glycerol as a by-product. Oil is extracted by using solvents hexane, diethyl ether by soxhlet apparatus. Marine vegetational biomass can acquire lipids with in their cells like extracted oils from vegetables with a possibility to deliver multiple times more oil than some other terrestrial vegetation. Aquatic macro and microalgal and sea grass biomass can play a vital role in solving the issue of excessive energy demand for the increasing human population through their mass usage in the biodiesel production in the future and can help to fulfill the expectations, while decreasing the emission of greenhouse gases. Nonetheless, all the serious challenges should be successfully overcome, before the implementation of large-scale commercial biodiesel production from the diversified aquatic vegetations.
\end{abstract}

Keywords - Aquatic vegetation, Biodiesel, Oil extraction, Sea grass, Trans-esterification

\section{INTRODUCTION}

Substantial and perpetual use of petroleum based fuels is generally accepted as unsustainable, because of the rapidly depleting supplies in overwhelming quantities and the participation of these fuels to the release of $\mathrm{CO}_{2}$ to the natural environment. Since the expense of unrefined petroleum keeps on going in an ascending trend, it has been proposed to explore the production of fuels from substitute sources in the future decades ( $\mathrm{Du}$ et al, 2008). In this scenario, biodiesel is one of the best alternative fuels due to its nontoxic nature (Lapinskiene et al, 2010). Biodiesel has stood out during the previous few years as a sustainable and ecofriendly fuel on account of lessening oil saves and the harmful ecological results of fume gases from oil diesel (Knothe et al, 2019; Vasudevan and Briggs, 2008). Biodiesel is the monoalkyl esters of long fattyacids, which is obtained from transesterification of bio mass (Lapueratasd et al, 2008). From the recent scientific findings, it has been proved that the oil yield from aquatic vegetation is clearly efficient to that of terrestrial plants such as palm, soybeans, grapeseed and it can completely replace fossil fuel (Spolaore et al, 2006; Chisti, 2007). Algae possess between 25 and $80 \%$ of the oil by the dry weight of the mass (Bajhaiya et al, 2010). Aquatic algal species have considerably elevated growth rates than the terrestrial plants and per unit area oil yield from algal species has been increased from 20, 000 to $80,000 \mathrm{~L}$ per acre, per year. This is eight times higher than the palm oil, which is the next best crop (Demirbas and Demirbas, 2011). Use of aquatic flora as energy crops has potential and significant role, because of their flexibility and adaptability to diverse developmental conditions, higher growth rate, capacity to grow on fresh water or marine waters without utilizing land facility (Khan et al., 2017).
Furthermore, more than $66 \%$ of the surface of the earth is covered with water, consequently algae would genuinely be sustainable alternative of extraordinary potential for global energy demands (Patil et al, 2008). Algal oil can also be used as a source of biodiesel (Demirbas and Demirbas, 2011). Diverse species of algae produces different types of biodiesel and bioethanol (Schenket et al, 2008) and this examination further represented that algal biofuels give off an impression of being the main sustainable source that could fulfill the worldwide need for transport energizes. Marine and fresh water algal species are one of the most efficient sources for the production of biodiesel and the improvised transesterification method for the biodiesel production and the physical properties of biodiesel should be studied carefully for each and every vegetation type separately (Hossain et al., 2008). Biodiesel production utilizing marine vegetation as source has expanded a long time to lessen the reliance on petroleum derivatives (Tan and Ang, 2019). In this review, the important steps of macroflora-based advanced methodologies developed to bioconvert diverse macrofloral biomasses to biodiesel and the economic contemplation associated with production, merits and demerits of biodiesel production from marine and freshwater floral species are discussed and summarized.

\section{AQUATIC FLORAL BIOMASS}

Marine and freshwater macroalgae are multicellular photosynthetic natural living sea weeds that are categorized under the lower plant class, since they have a thallus type non-developed leaves rather than stems, roots and leaves. Macroalgal size changes in a wide range, from microscopic forms $(3-10 \mu \mathrm{m})$ to huge naturally visible structures (up to $70 \mathrm{~m}$ ). Since aquatic macroalgae are photosynthetic biological organisms, most of them have chlorophyll, 
however they likewise contain additional pigments to survive and establish their arrangement (Guiry, 2008).

1. Brown algae (Division Phaeophyta)-Their main photosynthetic pigments are chlorophyll a and c, bcarotene, and xanthophylls. Ex: Sargassum sp, Turbinaria ornata

2. Red algae (Division Rhodophyta) — Red color is due to chlorophyll a, phycoerythrin, and phycocyanin. Ex: Gelidium species

3. Green algae (Chlorophyta division) - They have the same proportion of chlorophyll a to b like the terrestrial plants. Ex: Ulva faciata

4. Sea grass (Hydrocharitaceae)- They are marine sea grass known as "turtle grass". Ex: Thallasia sp

Generally, aquatic algae express a significant photosynthetic efficiency thus produce huge biomass than the other plant types (Guiry, 2008). Algae are very small plants that perform photosynthesis to convert $\mathrm{CO}_{2}$ and sunlight into chemical energy proficiently which they can increase their weight multiple times every day (Briggs, 2004). As a feature of the photosynthetic process, algae can produce multiple times more oil per acre of land than the other vegetational types utilized for biofuel production. Ex: corn and switch grass (National Biodiesel Board, 2009). Algal species can excessively grow in salt water, freshwater or even debased water. Aquatic algal species are the most efficient highyielding feedstocks for the production of biodiesel. An average sized aquatic algae can create up to more than 250 times of oil per acre of land as soybeans under conducive environmental conditions (Hossain et al, 2008).

Aquatic floral species function as potential sources for biodiesel production, for the following principle reasons: (1) The oil yield from marine and fresh water vegetation is higher than those for customary oilseeds, and (2) They can grow in any water sources, in this way limiting the harmful effects caused to the natural pecking order frameworks. As an advantage, algae can be filled in sewages and close to control plant smokestacks where they digest the toxins and pollutants through this it can produce natural oil. Such a methodology can be used to tackle serious issues of air pollution coming about because of the $\mathrm{CO}_{2}$ evolution and future crisis, because of the insufficient fuel sources. The tapping of designed algae to deliver bio-diesel and bioethanol has the best capability of incredible achievement since algae is slick where it has about $50 \%$ (half) oil composition. Aquatic algae and aquatic weeds are the quickest growing life forms and have gotten thick enough to be harvested three times a day (Hossain et al, 2008). In spite of the fact that investigation on algal oil as a source for biodiesel isn't new, the present oil shortages and quick draining of fossil oil holds have made it more basic for associations and nations to contribute more research on appropriate inexhaustible feedstock, such as algae. Algal community can be grown utilizing land and water that are not suitable for plant or food production. The vast majority of the oceanic, fresh water algae have the ability to deliver different biofuels since their cell apparatus is adjusted to play out various metabolic pathways efficiently (Figure 1). Actively growing algae consumes carbon dioxide, that gives greenhouse gas mitigation advantages (Khan et al., 2017).

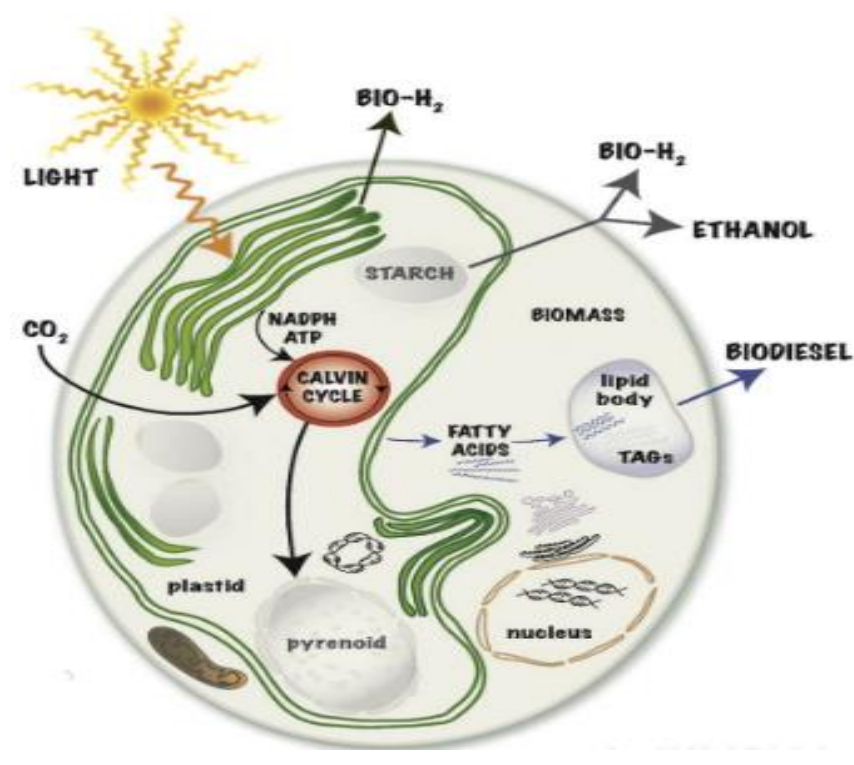

Figure 1: Metabolic pathways of the algal species involved in the production

\section{BIODIESEL PRODUCTION}

Biodiesel means, ester-based oxygenated fuels obtained from renewable, natural living sources such as animal fats and vegetable oil. Although biodiesel contains very different compounds than petroleum derived diesel, it has combustion properties very similar to the former including the energy content and cetane ratings. The production of biodiesel occurs by means of transesterification reaction between triglycerides (vegetable oil) and methanol and acidic or basic catalyst facilitate the reaction (Chisti, 2007; Li et al, 2007; Knothe et al, 2005). Petroleum derivative has right now become inadequate to fulfill overall interest because of the consumption of its provisions and the huge commitment of greenhouse gases, for example, carbon, nitrogen and sulfur oxides delivered during petro-diesel combustion (Brown,1993; Chisti,2008). The availability of biodiesel isn't generally spread far and wide, however there are lot of nations involving in this biodiesel industry, producing and consuming the fuel. Biodiesel has been developing to be alternative and elective fuel to the economy of the North American countries (Kadir et al, 2018). Biodiesel is commonly comprised of unsaturated fatty acid ester and at times unsaturated fatty acid ethyl ester molecules. Lipid antecedents of the ethyl ester molecules are stored in the lipid bodies. These are round organelles that store lipids, but at the same time are responsible for transporting lipids, storage of proteins and biodegradation and get involved in different 
roles. In the event that biodiesel is wanted, the strains that are able to produce higher lipid molecules will be highly preferred. Triacylglycerol (TAG) and other unsaturated fat subsidiaries work as auxiliary fuel source for the algal body and are frequently found in their cytoplasm. The biomolecules functions as both electron sources and energy reservoirs for the metabolic activities of algae. Light entering the algal cell and being consumed by photosystem, that cause an oxidation-reduction reaction that make electron scattered to higher energy level. These electrons are later transported by NADPH into Calvin cycle. The end products of this cycle are utilized to produce diverse precursors for starch and TAG (Onay and Melih, 2015).

Cell wall containing lipids and unsaturated fats of the marine algae and seagrass differ from that of higher plants and animals. Cell disruption strategies demonstrating the reasonableness and adequacy depend on the cell wall hardness, appropriateness for the large-scale usage, the degree of the lipid product withstand the contamination (toxicity), reusing capacity, cost and time and continuous maintenance (Suganthan et al., 2018). Cell disruption strategies that are in practice nowadays are of four major types. They are chemical, mechanical, biological and thermal. All these strategies might be applied individually or in different combination based on the type of marine flora. Among the 4 methods, the mechanical pre-treatment has been reported as the efficient technique as this is less dependent on the floral species and the chances of contamination of the lipid product would be very law (Kadir et al, 2018).

\section{AQuatic Vegetation AND Biodiesel PRODUCTION}

A large number of marine and fresh water plants belonging to different genera of macroalgae and microalgae, marine weeds, aquatic plants and microorganisms like yeast, bacteria and fungi have the ability to accumulate lipid molecules under the given cultivational conditions and produce biodiesel. The lipids found in microbial cells exist in unsaturated fatty acid forms and they have the potential to serve as a source of transportation (Brennan and Owende, 2010). Diverse microbial species can be chosen to produce different biofuels and the conditions can be later optimized in order to enhance the yield. Algae produce a large spectrum of valuable bioactive products such as human food, nutritional derivatives, animal feed, energizing substances, natural organic fertilizers, biodegradable plastic materials, transgenic proteins, photosynthetic pigments, medical drugs and pharmaceutical products, solution for pollution and vaccines against microbes. The energy sources mentioned above include bioethanol, gasoline, jet fuel, gas used for rockets and flights and biodiesel.

A homogenous cultivation method was developed for diverse aquatic weeds and algae (134 species from 68 genera) in the closed and opened balanced ecological systems to sue the plant species for space. This effort proved that it was beneficial to keep the conditions homogenous for the growth of aquatic weeds (Leghari, 2002) and a cyanobacteria Spirulina (Oguchi et al., 1989). Brown macroalgae, Sargassum sp can be an efficient marine source for the production of biodiesel. Quantity of the Biodiesel from Sargassum sp. was significantly increased by more than 11 times, after transesterification conditions were optimized and the higher density of the biodiesel $\left(867 \mathrm{Kgm}^{-3}\right)$ from this marine algal species matched the international standards (Fernando and Kapilan, 2020).

Screening of abundantly found diverse aquatic microalgal species such as Spirulina maxima, Nannochloropsis sp., Neochloris oleoabundans, Chlorella vulgaris, Scenedesmus, Scenedesmus obliquus and Dunaliella tertiolecta, was done to choose the best biodiesel producer depending on the amount and quality of the oil source and biofuel/ biodiesel (Gouveia 2009). Large amount of aquatic vegetation such as macroalgae, microalgae, aquatic weeds, phytoplanktons and aquatic grasses could be used as suitable raw materials for biofuel/ biodiesel production due to the existence / production of comparatively higher quantity of oil (more than $20.0 \%$ ). If the target is to produce biodiesel only from one vegetation type, then presence of adequate fatty acids needs to be considered (Hossain et al., 2008).

Aquatic green algal species of Oedogonium and Spirogyra were studied to compare the quantity of biodiesel produced by them after processing. Quantities of extracted oil and biodiesel was significantly higher in the different species of Oedogonium than Spirogyra sp. However, the biomass quantity obtained after the oil extraction was significantly higher in Spirogyra than Oedogonium sp. Therefore, biodiesel can be produced from both Oedogonium and Spirogyra and Oedogonium provides a better biological source for biodiesel than the Spirogyra species (Hossain et al., 2008). It has been proved that oil and biodiesel can be produced using the biomass of Sargassum sp., Turbinaria ornata, Ulva fasciata, Gelidium sp. and Thalassia sp. The organic solvents n-hexane and di-ethyl ether were used extract oil from these marine plant species, whereas the bioconvertion of the oil into biodiesel was done via transesterification reaction facilitated by alkaline catalysts (Fernando and Kapilan, 2020).

\section{HARVESTING AND DRYING OF AQUATIC BIOMASS}

Pretreatment of plant biomass includes the corruption or interruption of biomass to change over, assemble the carbohydrates and lipids. Reaping of floral substrate and drying it further are important before processing and extracting the solvents for the recuperation of oil. There have been different methods used in practice for harvesting of algae in order to perform the solid-liquid separation. The four categories of the methods are biological, chemical, electrical and mechanical means (Srivasatava et al., 2000). Microalgae collection is done by some conventional strategies, for example, centrifugation, sedimentation, film 
filtration, flocculation and foam buoyancy. Macroalgae can be gathered utilizing nets, that require very low energy while harvesting by some conventional methods, which incorporate filtration, flocculation, centrifugation, froth fractionation, sedimentation, foam floatation and ultrasonic partition are also in practice. Choice of harvesting strategy relies upon the kind of plant species. The selection of the harvesting strategy of marine floral species relies upon the crucial properties of algal such as macroalgal species, thickness, shape and size of the particle, composition of the cell wall and the economic value of the output from them (Kadir et al., 2018). Drying is a significant technique to expand time span of usability of the floral biomass prior to the storage, which stays away from post-harvest deterioration. Sun drying isn't considered as a compelling technique because of the higher level of water found in the biomass (Kadir et al., 2018).

\section{EXTRACTION OF OIL FROM BIOMASS}

When solvent is used in the oil extraction, almost all the oil will be recovered and less than $0.5 \%$ of residual oil will be left in the substrate or biomass. Therefore, the solvent extraction process is highly preferred over the mechanical method in order to extract oil and fats from marine algal species (Khola and Ghazala, 2012). Lipid extraction by solvent extraction method from marine algae and sea grasses has been proved as one of the effective method based on the net yield and the quality. The quantity of lipid extracted out from the plant substrate and biodiesel yield depend mainly on the type and chemical nature of solvent used. Hexane, di ethyl ether, acetone, cyclo-hexane, and benzene are some of the organic solvents used either solely or in combined form. The solvent reacts on individual algal cells that result in releasing the oil. This oil can later be recovered from the liquid medium. This is possible because oil is highly soluble in organic solvents than water. The separation of oil from the solvent extract is also very easy and includes a straight forward procedure. The solvent can be reused and recycled for the following extractions. Since hexane has great ability to extract oil with a boiling point of $69^{\circ} \mathrm{C}$, it is highly preferred among the diverse organic solvents available. At this temperature, hexane remain in liquid stage and it will retain its chemical features in diverse atmospheric conditions (Ryckebosch et al, 2012).

The serious drawback of the solvent extraction method of marine algae is the regular solvents (hexane and chloroform) are very toxic and cause adverse health hazards and environmental issues. In laboratory scale processes, oil extraction from floral biomass using organic solvents is done in batch process. The amount of lipid present in the plant biomass into the solvent attains an equilibrium point with the lipid concentration in the solvent that limits further relocation or transportation of lipid to the solvent in the extraction process done by batch method. This limitation could be overcome by the continuous usage of organic solvent extraction method could. However, using organic solvent continuously for extraction is very expensive, as this process needs a large quantity of organic solvents supplied continuously. During the evaporation of solvent and condensation cycles, soxhlet apparatus reloads plant substrates with newly prepared organic solvents and reduces the intake of solvent. The Soxhlet apparatus consists of three important compartments: a heating round bottom flask, soxhlet extractor that holds the plant substrate and a condenser which functions to cool the element (Prafulla et al, 2005).

Biodiesel is produced by the trans-esterification reaction of fats and oils by the addition of methanol (or any alcohols) and a facilitater/catalyst, that yields glycerol as a co-product (Figure 2 and 3). The oil is extracted from the source of vegetation biomass (marine macro and micro algae, sea grass, or any other marine vegetation) via chemical or mechanical processes. The fat/ oil is mixed with an alcohol (usually methanol) and this reaction is enhanced by a catalyst added in the bioreactor. This reaction occurs at relatively low temperatures $\left(140^{\circ} \mathrm{F}\right)$ and low pressure and produces a crude biodiesel and glycerine. Catalysts used in this process are 1. Base $-\mathrm{NaOH}, \mathrm{KOH} 2$. Acid $-\mathrm{H}_{2} \mathrm{SO}_{4}, \mathrm{H}_{3} \mathrm{PO}_{4}$. Sometimes, methanol of fossil origin is replaced by bioethanol where fatty acid ethyl ester will be produced instead of fatty acid methyl ether (biodiesel). Later, the excess alcohol needs to be removed from the biodiesel and from the glycerine and recovery is processed by distillation (Ryckebosch et al, 2012).

\section{TRANSESTERIFICATION}

There have been different methods of producing biodiesel from diverse vegetable oils and fats and all these methods utilize triacylglycerol directly or materials that have triacylglycerol. There are four basic technologies that are in practice across the globe and the direct methods are blending with petroleum-driven diesel fuel system, microemulsification, thermal cracking and trans-esterification. Among them, transesterification is the most efficient and economically advanced process, because of the low temperature and protective pressure usage that gives relatively high biodiesel yield (Knothe et al, 2019). Transesterification is the direct and easy way to produce biodiesel from vegetable and algal oils (Figure 2). The transesterification reaction takes place using primary or secondary monohydric aliphatic compound having less than 8 carbon atoms. Alcohol types that involve in the

\section{Transesterification:}

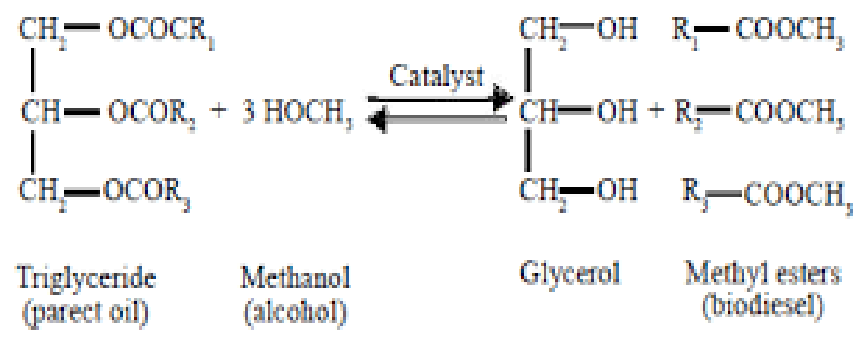

Figure 2: Transesterification reaction step in the biodiesel production

(Hossain et al., 2008) 


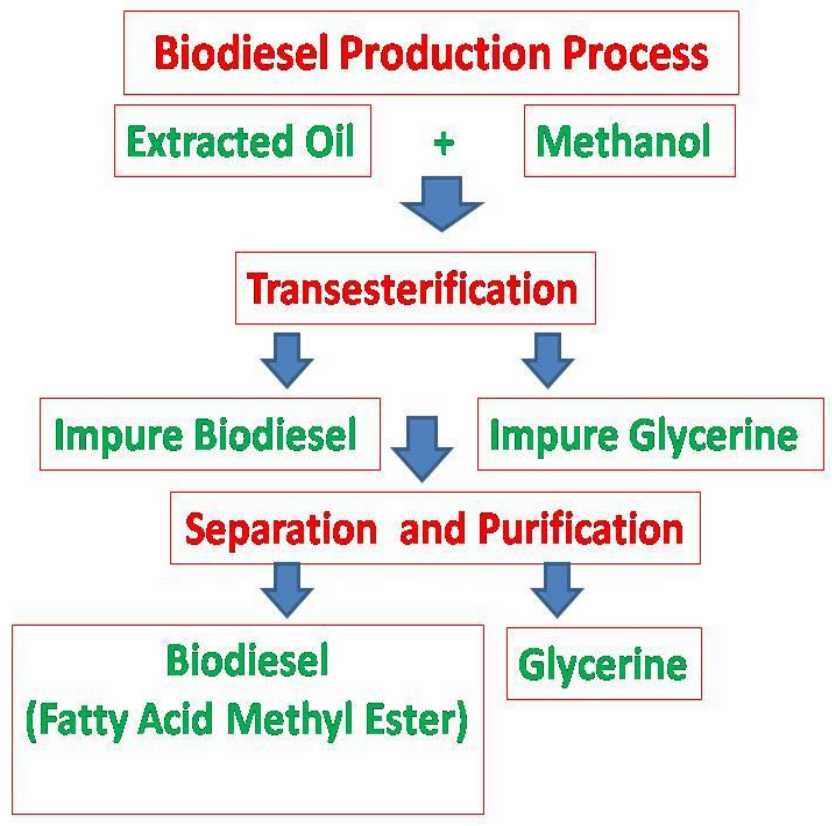

Figure 3: Basic steps involved in the biodiesel production

transesterification reaction are methanol, ethanol, butanol and amyl alcohol. However, methanol is highly preferred because of its cost effectiveness and its advantages in the physical and chemical properties. Methanol is polar component and it possess a shorter chain. Triacylglycerol's (vegetable oils and fats) are the esters of carboxylic acid and they can be bioconverted into methyl esters by transesterification process. Temperature of the reaction, amount of water, reaction pressure, molar ratio, and free acid component are the factors that affect the methyl ester formation. The ester yield increases with the oil to alcohol molar ratio (Ramachandran et al, 2013).

Transesterification involves a series of continuous and reversible reactions. Here, triglyceride is gradually converted into glycerol through the stepwise production of diglyceride and monoglyceride. Usage of catalyst in this reaction will facilitate the transesterification processand triggers the reaction rate. The catalysts can be homogeneous or heterogeneous and acidic or basic in nature. Biodiesel production from homogenous alkaline catalysts had multiple advantages over acid catalysts. Advantages are the rate of transesterification reaction is faster and the conditions required are minor, acid-catalyst needs a higher methanol to oil molar ratio, the methanol consumption is very low at higher concentrations of acid catalyst. Commonly use alkaline catalysts are $\mathrm{KOH}, \mathrm{NaOH}, \mathrm{NaOCH}_{3}$ and $\mathrm{KOCH}_{3}$, while the acid numbers to get the maximum yield using $\mathrm{NaOCH}_{3}$ are significantly lower than $\mathrm{NaOH}$. In the industrial biodiesel production, $\mathrm{NaOH}$ is widely used as alkaline catalyst due to its effectiveness, availability and less cost. $\mathrm{NaOH}$ is used in large scale transesterification of marine algal biomass because of its high purity and cheapness. When compared to $\mathrm{KOH}$, relatively very small quantity of
$\mathrm{NaOH}$ is enough for effective transesterification reaction (Knothe et al, 2019; Meka et al, 2007).

Heterogeneous catalysts increase the rate of transesterification by reducing the extra processing costs involved in homogeneous catalysis, as well as minimizing the amount of pollutants released (Xie et al, 2007). Heterogeneous catalysts can withstand higher number of free fatty acids and higher moisture content. These catalysts not only involve in easy recovery from the reaction mix and reusability but they are commercial cost-effective substances. Through the usage of efficient and cost-effective heterogeneous catalysts the overall cost for the biodiesel production is minimized (Refaat et al, 2010). Heterogeneous catalysts are the integral factors like higher temperature and pressure. These catalysts can be easily separated from the reaction mixture, are capable of tolerating concentrated aqueous treatment procedures and are amenable to motivate to get increased activity and long-lasting functions (Meka et al, 2007).

Methanol has been best suited as the source alcohol for the trans-esterification process since it facilitates the reaction very fast and helps to isolate good quality ester. The speed of the trans-esterification reaction is relatively low with regular ethanol, and the recovery of ester from the bioreactor is very low. The effect of different alcohols on biodiesel production using diverse vegetable oils has been studied. Methanol can react effectively with vegetable oils than the other common alcohol types. Biodiesel production with the combination of methanol and ethanol is also very effective because the purity of the ethanol is less than that of methanol alone. Getting ethanol procurement is very difficult and expensive compared to other alcohol types (Singh et al, 2007). In the conventional biodiesel production, alcohol will be employed as an acyl acceptor that produces side product, glycerol. Therefore, industries that involve in the biodiesel production now tend to produce excessive quantities of glycerol, which would lead to the fall of biodiesel prices in the world market substantially (Tan and Ang, 2019).

Other than reduced emission of greenhouse gases that cause global warming, environment friendliness, capacity to reduce dependency on foreign oil, lubricating the engine itself and the role in decreasing engine wear are the most fantastic benefits of the usage of biodiesel from marine flora over the conventional biodiesel. Almost all diesel vehicles with minor or no modification of the engines can run on biodiesels (Hossain et al, 2008).

\section{A. Carbon neutral combustion}

Chemical structure of the algal biofuels is beneficial because it absorbs most of the carbon it releases. It would be ideal if a fuel source is renewable and eco-friendly without polluting the environment which creates a negative impact on our natural environment. Even if the consumption is at very high level, then its mean existence should be stabilized (Khan et al, 2009). Another advantage of using marine algae as source 


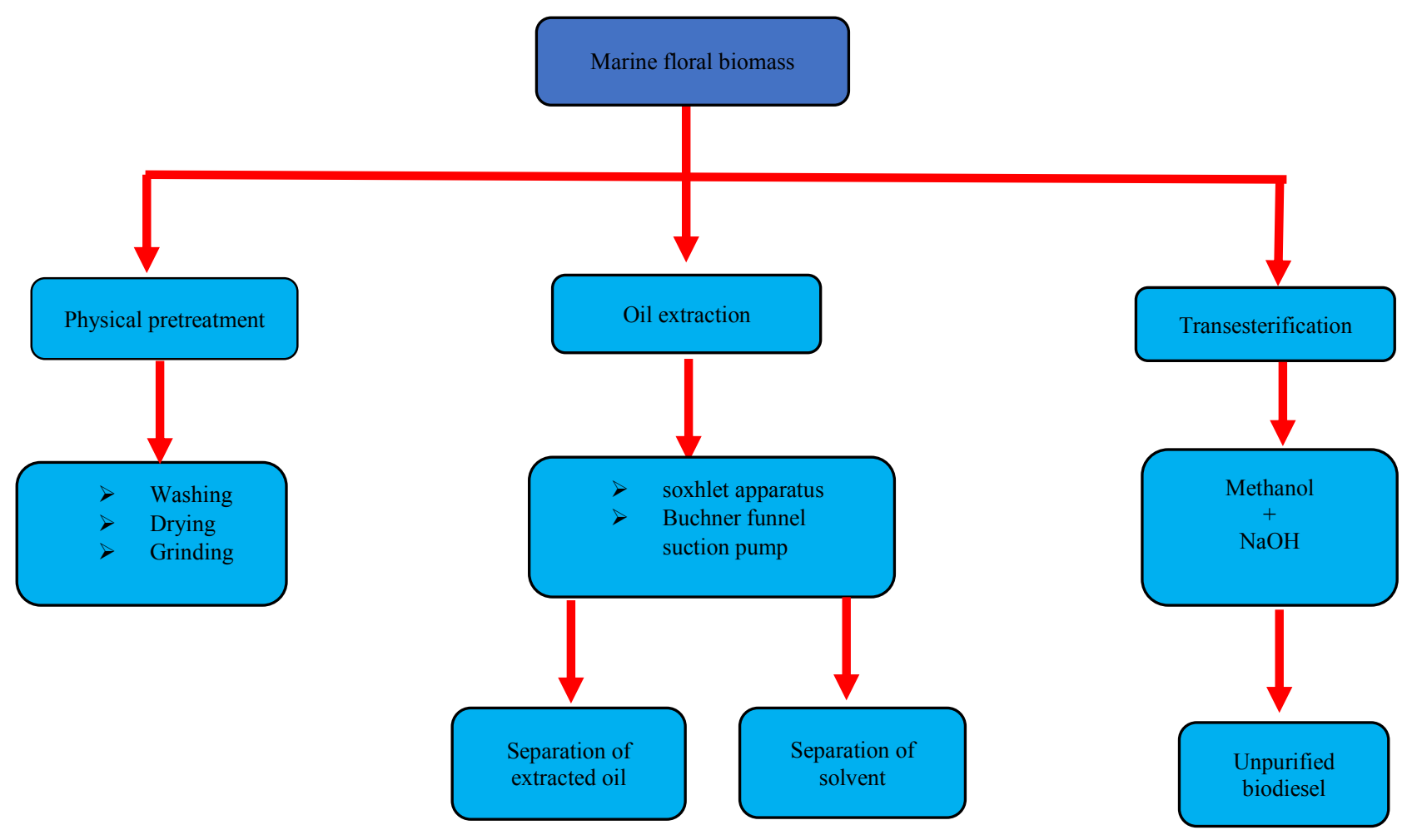

Figure 4a: Process of biodiesel production from marine flora (Khan et al, 2015)

for biofuel and biodiesel is that it would become a direct and immediate replacement for all the fuels that we already use in diverse industrial applications. The biodiesel products are refined or purified in a similar way as the petroleum products. Two international airlines such as Qantas and United Airlines have tried the aircraft engines powered by biofuel obtained from algal blend and have obtained a successful output (Gendy et al, 2013).

\section{B. Production of multiple by products}

Hydrocarbons can be used from plants-based materials as the same way it is used from petroleum-based items. Production of fertilizers, cleaners, soap products, perfumes and feed stocks are some of the usages. The algae should be in abundance and the refinery processes could be profitable, efficient and can be done easily. The biodiesel and its byproducts are useful similarly as the regular diesel fuels (Briggs, 2004).

\section{Natural Abundance}

Marine algae have the capacity to double their size in one day. Different marine algae exist and grow in diverse depth of the water resources, including in the artificial water supplies (Demirbas, 2008).

\section{Renewable resource:}

Since algal source is renewable and can last longer, there is no need to explore new sources like the fossilized products. If there is a need to have more, then algae can be subjected to natural multiplication (Mellinda et al, 2008).

\section{E. Decrease the food shortage}

Most biofuels have been produced from natural products and food related crops. If oil and biodiesel are produced by processing of marine vegetation, then the issues related to destruction of food related terrestrial crops will be highly minimized (Teresa et al, 2010). There is an advantage that marine algae are not directly used in the regular human food therefore, it will not get involved in the food chain directly (Hossain et al, 2008, Teresa et al, 2010).

\section{DRAWBACKS OF BIODIESEL PRODUCTION FROM AQUATIC FLORA}

\section{A. Disturbance of environmental equilibrium:}

Harvesting of marine vegetation has some environmental merits and demerits. Based on the harvesting methods and the harvesting sites, these will affect sustainability of the environmental, including wildlife disturbance or other environmental equilibrium. Overharvesting, due to mechanical harvesting, can significantly affect the marine plant biodiversity. If economic efficiency and effectiveness are considered, the manual harvesting has been better than the harvesting using machineries (Ghadiryanfar et al, 2016).

\section{B. Need of large amount of water}

Regardless of the growing place of the algae, there should be a prominent water source available for the algal species to increase the growth. When temperature is maintained at an appropriate level to enhance exponential growth, then the aqueous solution will start to evaporate. That is one of the 
reasons that biofuel utilizes fair amount of water. Even though waste water recycling and natural farming process could reduce this demerit to a certain level, there is still the challenge of water diversion taking place when there is an opportunity (Teresa et al, 2010).

\section{Need of fertilizer use}

Algae can be grown in large quantities only when there is enough quantity of fertilizers available. There is a need of 15 million metric tons of nitrogen to produce sufficient algae to create 39-40 billion liters of biodiesel, along with 2 million metric tons of phosphorus. Since important nutrients come from petroleum-based products, it shifts the needle on carbon neutrality to a certain level. There is also a threat of nutrient run-off into the local waterways which would create huge environmental and health hazardous situation (Jason et al, 2015).

\section{Production cost is high:}

Technology needed for the production of biofuels and biodiesels are very expensive nowadays. Initial capital investment being put into a biodiesel production plant is comparatively low. If the demand of biodiesel increases, then expensive bioreactors, skilled laborers and sophisticated technology are required for the large-scale biodiesel production which would be very expensive (Knothe et al, 2019).

\section{E. Time consuming}

Although most of the algal strains are harvested in a day, the biodiesel and bioethanol produced cannot be consumed immediately. There are several steps that need to be carefully followed before using the biofuel source. The oil press is one of the fastest and efficient ways to extract oil from the marine algae. The extracted oil needs to be refined using fatty acid chains and this process is called transesterification. However, the production of petroleum fuels is faster than the biofuels (Singh et al, 2011, Ghadiryanfar et al, 2016).

\section{F. Regional suitability issues:}

Varying climates throughout a geographic location of the globe determines the types of crops that could be cultivated. Marine vegetation that includes marine macro and micro algae and marine grasses will grow better in specific regions of marine water than others if outdoor cultivation methods are practiced. Although marine algae get substantial benefits through weather tolerance, they have the flexibility to grow on places where there is extreme cold (Scoot et al, 2010).

\section{G. Low efficiency in energy usage}

When biofuels like biodiesel from marine algae take the energy equivalent of several gallons worth of a petroleumbased fuel to produce a single gallon of the environmental friendly type. Usage of advanced farming techniques, results in the production of more energy containing algal biofuel when compared to the energy it contains (Scoot et al, 2010).

\section{H. Issue of monoculture}

When one type of a crop is grown in concentrated manner, then the chances of the crop and its products getting attacked by the pests and pathogens would be very high. Therefore, it is important to rotate the vegetation types and avoid having monoculture practices when growing plants for oil and biodiesel production (Scoot et al, 2010).

\section{APPLICATIONS OF BIODIESEL}

\section{A. Help in transportation}

Production of biodiesel from natural underutilized sources for transportation has been increasing tremendously. Nowadays, gasoline and diesel are the two main type of

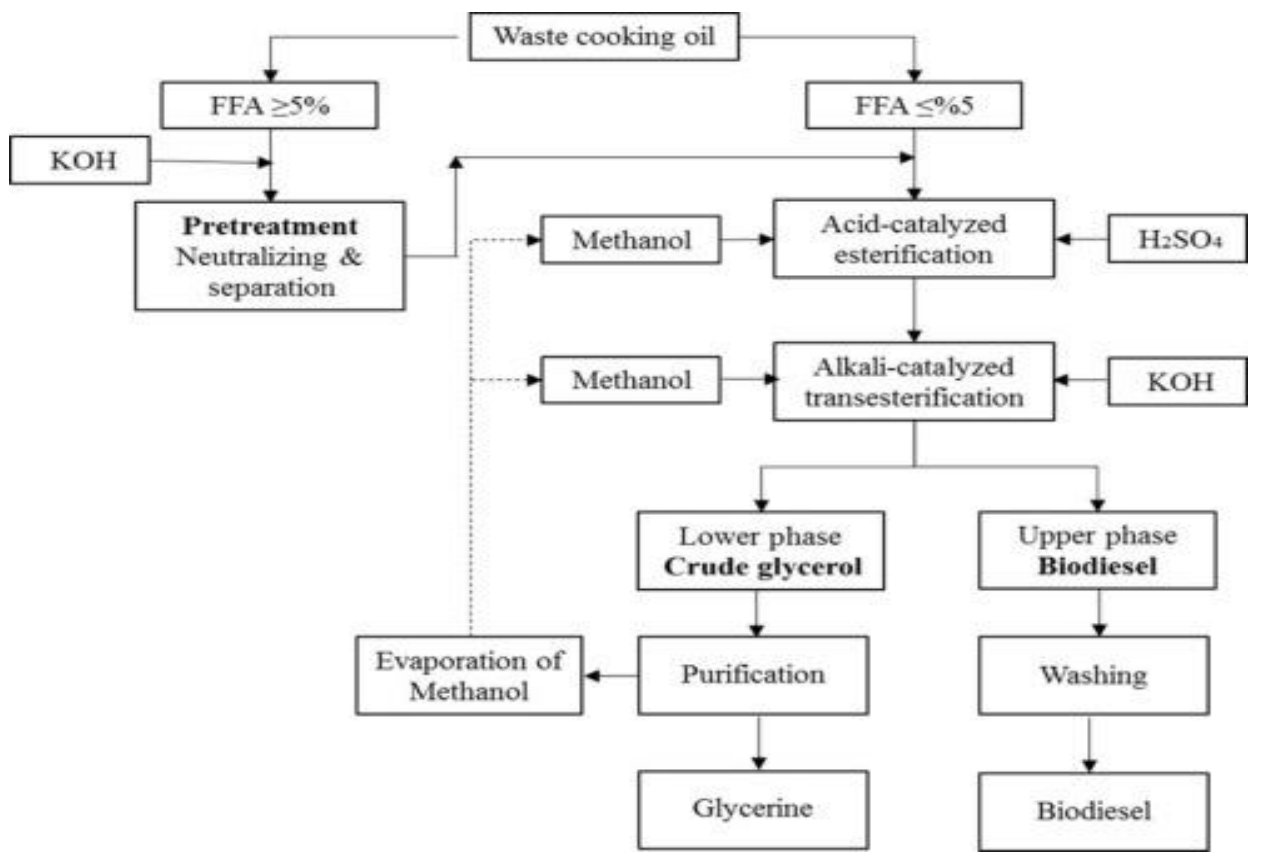

Figure 4b: Schematic flow Process of biodiesel production from biomass source (Win \& Trabold, 2018) 
fossil fuels used in transportation. These fossil fuel types can be replaced with biofuels derived from a series of algal biomass (bioethanol and biodiesel). Biofuels like methanol, ethanol and biodiesel are highly oxygenated compounds thus their emission will be very clean during the process of combustion. Generally, biofuels are good performers during combustion than the fossil fuels, (Ghadiryanfar et al, 2016). When fossil fuel is mixed with pure biofuels or biodiesel then the performance of the internal combustion engine would be better (Demirbas, 2008). Algal biofuels play a vital role in reducing the global emission of greenhouse gases. This is because are considerable amount of the $\mathrm{CO}_{2}$ is released from transport fuels(Veillette et al, 2007). The European Energy Commission has been promoting aviation industries to use biofuel by the year 2020 in order to reduce the GHG emission in Europe (Fasahati et al., 2015).

\section{B. Generation of energy}

Biofuels such as biodiesel derived from marine and terrestrial algae can be used in produce electricity. Biofuel and biodiesel from marine vegetation have great potential to substitute fossil fuel for engine combustion. Electricity can be generated using wide range of marine microalgae in coal co-firing to reduce greenhouse gas emission and minimize the coal utilization (Milano et al, 2016). Huge amount of electric power generated via coal power plant has great impact towards having a pollution free/ less environment (Kucukvar et al, 2011).

\section{Value added products}

Diverse value-adding products and co-products are produced by recycling and post- processing the biomass and this process yields animal feed with good quantity of nutrients. This process facilitates nutrient recycling to some extent, but is limited to the certain value added to the entire system. Algae produce diverse natural co-products of higher value that have a great market demand (Ghadiryanfar et al, 2016). Marine plant species that have both high lipids, and prominent secondary metabolites of human use can be used as a biomass source for biodiesel production. Production of natural co-products by a plant species and relevant species can be made to produce more by through genetic engineering. Heterologous proteins or metabolites can also be produced from marine algae through bioengineering process. Production of high-value natural or synthetic components has great potential in determining the demand and price for algae-based bioethanols and biodiesel (Hannon et al.,2010).

\section{Application in the environment}

Outcome of greenhouse gas emissions $\left(\mathrm{CO}_{2}, \mathrm{CH}_{4}\right.$, and others) could be highly minimized by using biofuels and this is related to the quantity and carbon intensity of the fossil fuel inputs required for the biofuel production, as well as to the type of fossil fuel that is substituted by usage of the biofuel/biodiesel. An appropriate greenhouse gas accounting contemplates the complete life cycle of the biofuel/biodiesel, from the early plant stage and accumulating the biomass to conversion of the biomass to biofuel, to combustion of the biofuels at the time point of usage (Chisti, 2007).

\section{E. Agriculture accessories}

Pesticides and fertilizer could be carried by the biodiesel in agriculture sprays because of the non-toxic and biodegradable properties of biodiesel (Dianursanti et al, 2015).

\section{F. Clean oil spills and grease}

Since biofuels are very environmentally-friendly, they are used to clean up oil spills and grease dirt. Biodiesel has been proved as an efficient cleaning agent for crude oil contaminated water resources. The action of recovery from contamination has been proved faster compared to the regular fuels. Biodiesel can also be used as an industrial solvent for cleaning metal, which is also beneficial due to its lack of toxic impact (Dianursanti et al, 2015).

\section{G. Lubricating Agent/Additive}

Naturally available biodiesel is used as a lubricating agent/enhancer in many industries and marine applications, particularly when water contamination with petroleum lubricity agents create functioning issues. According to the regulations for the usage of regular low-sulfur fuel in the future, biodiesel can be a good substitute as a lubricity additive. If lower percentage (1-2\%) of biodiesel is added to the regular diesel fuel, it would increase lubricity of the diesel by 65\% (Yue, 2013). Further, excessive usage of biodiesel increases the emission of NOx in the atmosphere (Knothe et al, 2019).

\section{ENVIRONMENTAL IMPACTS OF BIODIESEL}

Although the production of biodiesel emits carbon dioxide, a major greenhouse gase, the plants absorb carbon dioxide for photosynthesis from the atmosphere during growth. Though there can be serious consequences of turning over foodproducing land to planting the suitable plant for the biodiesel production.

$\mathrm{CO} 2$ emission will be highly reduced if biodiesel production is done from used cooking oil. Further, biodiesel can reduce the emission of particulates directly to the environment from running vehicles when compared to low-sulfur diesel. Marine vegetation has emerged as a favourable and positive feedstock for future biofuels due to the higher energy deposits, energy yield per acre, rapid growth rate and ability to grow in diverse quality of water. Algae have the capacity of producing more than 100 times more oil per acre than the terrestrial crops that are widely used for oil-production. Because of its high energy deposits, oil from algae can be refined into biodiesel and other form of fuels. Moreover, marine vegetation requires only water, sunlight, and $\mathrm{CO} 2$ to grow rapidly and establish (Knothe et al, 2019).

The biodiesel production has become an important step in the economy that enhances researchers to explore alternative pathways to resolve this issue. One of the solutions is to use 
alternative solvents to replace alcohol and to synthesize a new side product. As an example, glycerol-free biodiesel is produced by utilizing methyl acetate has been promoted. Here, instead of underutilized glycerol, triacetin is produced as a side product. Triacetin is widely used in pharmaceutical, vehicle producing and cosmetic industries. Therefore, the recent trend is production of glycerol-free biodiesel with the involvement of methyl acetate as an alternative solvent (Tan and Ang, 2019).

\section{CONCLUSION}

Marine algae and seagrasses that are widely spread all over the marine ecosystem are an important source for biodiesel production because of their abundance, existence at different depth of water resources and eco-friendly properties. Marine floral biomass involves in finding a solution for the issue between the production of food and that of biodiesel in the near future and can help to meet the notified requirements, while reducing greenhouse gas emissions. However, we need to encounter multiple challenges and successfully overcome them, before using marine vegetation substrates as source for large-scale commercial biodiesel production.

\section{REFERENCES}

Abd El-Moneim, M.R.Aflfy, Emad A.Shalaby and Sanaa M.M.Shanab. (2010). Enhancement of Biodiesel production from different species of algae. 416-422.

Abdul Majeed Khan, N.Fatima.N.Ammen. (2017). Production of green and renewable biodiesel from marine algae Sargassum Tenerrimum. Geo-marine sciences, 815821.

Ahmed, A. S., Khan, S., Hamdan, S.,.Rhaman,M.D.R., Islam, M. D.S. and Maleque, M. A. (2012). Biodiesel production from macro algae as a green fuel for diesel engine. Engineering towards change-empowering green solutions, 393-398.

Adel, A (2015). Production of biofuels from the green alga Tetraselmis. 28-34.

Aransiola, E.F., Ojumu, T.V., Oyekola, O.O., Madzimbamuto, T.F., Ikhu Omoregbe., D.I.O (2014). A review of current technology for biodiesel production :State of art. biomass and bioenergy, 276-297.

Bajhaiya, A.K.,S.K.Mandora, M.R.Suseela,K.Toppa, S.Ranade. (2010). Algae biodiesel :The next generation biofuel for India. Asian Biological Science, 1(4): 728-739.

Balasubramanian.S.Allen.J.D,Kanitkar.A.,Bolder.D.,(2011)O ilextraction from Scendemus obliquusnusing a continuous microwave system design optimizationa and quality characterization.,Bioresource technology:102:3396-3403
Balat. M. (2010). Progress in biodisel processing. Applied engineering, 87:1815-1835.

Beer. L,E.S. Boyd, J.W.John., M.C.Posewitz, J.W.John., M.C.Posewitz. (2009). Engineering algae for biohydrogen and biofuel production. Current opinion in Biotechnology,20(3):264- 271.

Brennan, L., \& Owende, P. (2010). Biofuels from microalgae - a review of technologies for production, processing, and extractions of biofuels and co-products. Renewable and sustainable energy reviews, 14(2), 557-577.

Chen, M. , Liu, T. , Chen, X. , Chen, L. , Zhang, W. , Wang, J. , (2012) Subcritical co - solvents extraction of lipid from wet microalgae pastes of Nannochloropsis sp. European Journal Lipid Scince Technology, 114: 205 - 12.

Chisti, Yusuf. (2007). Biodiesel from microalgae. Biotechnoloy advances, 294-306.

Prommuak, C. Pavasant, P. Quitain, A. T. Goto, M. Shotipruk, A. (2012) "Microalgal Lipid Extraction and Evaluation of Single-Step Biodiesel Production", Engergy. Journal.:(16):5, 157- 166

Demirbas, Ayhan. (2009). Progress and recent trends in biodiesel fuels. Energy conservation and management, 1434.

Demirbas.A, D. Faith. (2011). Importance of algae as a source of biodiesel. Energy conservation mangement, 52:163-180.

Dianursanti, M. Delaamira, S Bismo and Y Muharam.(2016). Effect reaction temperature on biodiesel production from Chlorella vulgaris using $\mathrm{CuO} /$ Zeolite as heterogeneous catalyst. Tropical and coastal region eco development, 1-5.

Dianursanti, Pijar Religia, Anondho Wijianark.(2015). Utilization of $\mathrm{n}$-Hexane as co-solvent to increase biodisel yield on direct transesterification reaction from marine microalgae.Tropical and coastal region eco-development, 412-420.

Du, W., Li, W,. Sun, T., Chen, X. Liu. S. (2008). Perspectives for biotechnological production of biodiesel and impacts. Applied microbiology and Biotechnology, 79:331337.

Fan, Xiohu. (2008). Optimization of biodiesel production from crude cottonseed oil and waste vegetable oil:conventional and ultrasound radiation methods. 63-126.

Fasahati P., Woo H.C, Liu, J. (2015). Industrial scale bioethanol production from brown algae effect of 
preteatment process on plant economics .,Applied technology.,139:175-187.

Fernando, M.N. and Kapilan, R., (2020). Small scale biodiesel production from Sargassum sp and optimization of conditions for yield enhancement. Journal of Science, 11(1), pp.23-36.

Fukuda.P., Konda.A,Noda. (2001). Biodiesel fuel production by transesterification of oils. Bioenergy resourse, 92:405416.

Gendy., T.S. and Temtamy, S.A. (2013). Commercial and potential aspects of microalgae for biofuel production.,Egyptian journal of petroleium.,(22):1:43-51.

Gerpen, Jon Van.(2005). Biodiesel processing and production. Fuel processing technology, 1097-1107.

Ghazala, B. and Khola, G.A. (2012). Biodiesel production from algae. 379-381.

Ghadiryarfar.M.,

Kurat.A. Rosentrater.,Keyhani.A.,Omid.M., (2016), A review of microalgae production with potential applications in biofuela and bioenergy.,Renewable and sustainable enery.,54:473-481

Guiry, M.D. 2012. The Seaweed Site. Information on marine algae. Journal of Algal research,48:5

Halim, R., Gladman, B., Danquash, M.K and Webley, P.A. (2011). Oil extraction from microalgae for biodiesel production.,Bioresource technology.,102:178-185

Hossan, A.B.M.S., Salleh, A. Boyce, A.N. Chowdhury, P. Naquiddin, N. (2008). Biodisel fuel production from algae algae as a renewable energy. Biochemistry and Biotechnology, 250-254.

Hossain, A. S., Salleh, A., Boyce, A. N., Chowdhury, P., \& Naqiuddin, M. (2008). Biodiesel fuel production from algae as renewable energy. American journal of biochemistry and biotechnology, 4(3), 250-254.

Ihsanullah, Sumaira Shah, Muhammad Ayaz,Iftikhar Ahmed, Murad Ali, Naveed Ahmad and Irshad Ahmad. (2015). Production of biodiesel from algae. Pure and applied microbiology, 79-85.

Iqbal.J.,Thegalla.C.,(2013)., Microwave assisted lipid extraction from microalgae using biodiesel as aco solvent.,Algal resource.,:(2),34-42

Jason.C.,Quinn.,Davis.R.,(2015).,The potential and challenges of algae based biofuels-a review of techno economic,life cycle, and resource assessment modelling.,Bioresource technogy.,184:444-452
Kadir.A., Lam.M., Uemura.Y., Lim, J. (2018).,harvesting and pretretment of microalgae cultivated in waste water for biodiesel productio;a review.,Energy conservation and mangement.,:171:,1416-1429

Kanthavelkumaran, N. and Seenikannan, P. (2012). Recent trends and applications of biodiesel. Engineering research and applications, 197-203.

Khan, Sarfaraj. (2012). Biodiesel production from macroalgae as a renewable energy source. 3-36.

Khan.N.A, Dessouky.E.H.(2009). Prospect of biodiesel in pakistan. Renewable sustainable energy resource, 13:15761583.

Khoo.H.H.,Sarath.P.N.,Das.P.,Balasubramanian.R.K.,Naraha risetti.P.K.,Shalik.S.,(2011).,Life cycle energy and Co2 analysis of microalgae -to-biodiesel:preliminary rsults and comparisions.,Bioresource technology.,:102,5800-5807

Knothe, G., Razon, L.F. Ellenita, M. \& de Castro, G. (2019). Methyl esters (biodiesel) from Melanolepis multiglandulosa (alim) seed oil and their properties, Biofuels,10:(2)239-243.

Knothe, Gerhard. (2005). Dependence of biodiesel fuel properties on the structure of fatty acid alkyl esters. Fuel processing technology, 1059-1070.

Kucukvar M, Tatari O. (2011) A comprehensive life cycle analysis of cofiring algae in a coal power plant as a solution for achieving sustainable energy. Energy ;36(11):6352-7

Kutney, Gerald. (2017). A short history of biofuels. Sustainable management, 28-36.

Lapinskiene, A.,Martinkus,P.Rebzdaite. (2006). Ecotoxicological studies of diesel and biodisesl fuels in aerated soil. Environmental pollution, 142.

Lapuerta, M, Armas, O., Fernandez, J. R. (2008). Effect of biodiesel fuels on diesel engine emissions. Progress energy Combustion, 34:198-223.

Lee, D. (2011). Algal biodiesel economy and competition among biofuels. Bioresource technology, 102:43-49.

Leghari, M. K., Shah, M., \& Leghari, M. Y. (2002). Ecological study of algal flora of Jhelum river-Azad Kashmir. Journal of Drainage and Water Management, 6(2), 33-48.

Leung, D.Y.C. and Guo, Y. (2006). Trasesterification of neat and used frying oil: optimization for biodiesel production. Fuel processing technology, 883-890.

Levine, R.B. , Pinnarat, T. , and Savage, P.E. (2010) Biodiesel production from wet algal biomass through in situ 
lipid hydrolysis and supercritical transesterification. Energy Fuels, 24: 5235-43.

Ma.F, Hanna.M.A. (2009). Biodiesel production. Renewable energy, 70:1-15.

Madan lal Verma, Collin J, Barrow,Munish Puri. (2013). Nanobiotechnology as a novel paradigm for enzyme immobilization and stabilisation with potential applications in biodiesel production. appiedl microbiol biotechnology, 97:23-39.

Mehar LC., Vidya sagar.D,Naik.SN. (2006). Technical aspects of biodiesel production by transesterification. Renewable sustainable energy, 10:68-248.

Mellinda J.Griffiths, Susan T,L.Harrison. (2008). Lipid productivity as a key characterisitic for choosing algal species for biodisel production. Applied Physology, 21:493507.

Mercer, P. , and Armenta, R.E. (2011) Developments in oil extraction from microalgae. European Journal Lipid Scince Technolony, 113: 539-47.

Michael Hannon, Javier Gimpel, Miller Tran, Beth Rasala \& Stephen Mayfield (2010) Biofuels from algae: challenges and potential, Biofuels, 1:5, 763-784

Milano.J.,Ong.H.C.,Masjuki.H.H.,Chong.W.T.,Mankeelam., Pingkwanlob.,V.Vellayan.,(2016). Microalgae fuels as an alternative to fossil fuel for power generation., Renwable and sustainable energy review.,:58:180-197

Moumita Chakraborty, Chao Miao, Armando McDonald, Shulin Chen. (2012). Concomit extraction of bio-oil and value added polysaccharides from Chlorella sorokiniana using a unique sequential hydrothermal extraction technoloy. Fuel, 63-70.

Mulumbo, N. and Knongolo. (2010). Production of biodiesel from microalgae. 28-54.

Oguchi, M., Otsubo, K., Nitta, K., Shimada, A., Fujii, S., Koyano, T., \& Miki, K. (1989). Closed and continuous algae cultivation system for food production and gas exchange in CELSS. Advances in Space Research, 9(8), 169-177.

Onay, Melih. (2015). Bio fuel production from microalgae. 23-34.

Patil.P.D, Gude.V.G., Mannarswamy.A, Deng.S,S. Cooke,P., MunsonMcGee, Rhodes.I, Lammers.P, Nirmalakhandan, P. (2011). Optimization of direct conversion of wet algae to Biodiesel under superficial methanol conditions. Bioresource technology, 102:118-122.
Peer M.Schenk, Skye.R.Thomas-hall,Evan Stephens,Ute C,Marx.Jan H Mussgnug,Clemens Posten,Ben Hankamer. (2008). Second generation biofuels: high efficency microalgae for biodiesel production. Bioenergy resource, 1:20-43.

Prafulla D.Patil, Shuguang Deng. (2009). Optimization of biodiesel production from edible non-edible vegetable oils. Fuel, 1302-1306.

Pramanik.K. (2003). Properties and use of Jatrophacurcas oil and diesel fuel blends in compression ignition engine. Renewable energy, 28:239-248.

Ramachandran, K.. Suganya, T. Nagendra Gandhi, N. Renganathan, S. (2013). Recent developments for biodiesel production by ultrasonic assist transesterification using different heterogeneous catalyst: A review Renewable and Sustaintainable Energy Resource, 22, 410-418

Rawat.I, Kumar R.R,Mutanda .T,Bux.F. (2013). Biodiesel from microalgae : A critical evalution from laboratory to large scale production. Applied engineering, 444-467.

Rocio Maceiras, Monica Rodriguez,Angeles Cancela, Santiago Urrejola, Angel Sanchez. (2011). Macroalgae:raw material for biodiesel production. Applied energy, 33183323.

Ryckebosch, E., Muylaert, K. and Foubert, I. (2012). Optimization of an analytical procedure for extraction of lipids from microalgae. Journal of American Oil Chemists' Society, 89: 189-98.

Scoot.H.C.,Davey.M.P.,Dennis.J.S.,Horst.I,HoweC.J.,Lea Smith.D.Alison Smith.,(2010) Biodiesel from algae: Challenges and prospects., Current opionion in biotechnology.,(21):3:,277-286

Shaila Siddiqua, Abdullah AL Mamun and Shekh Md.Enayetul Babar. (2015). production of biodiesel from Coastal macroalgae (Chara vulgaris) and optimization of process parameters using Box-behnken design. 4:720.

Singh, A.K.; Fernando, S.D.; Hernandez, R(2007). BaseCatalyzed Fast Transesterification of Soybean Oil Using Ultrasonication. Energy Fuels, 21, 1161-1164.

Spolaore, P., Joannis-Cassan, C., Duran, E. and Isambert, A. (2006). Commercial application of microalgae. Bioscience and Bioengineering, 87-96.

Srivasatava.A., Prasad.R. (2000). Triglycerides-based diesel fuels. Renewable sustainable energy, 4:111-113.

Sukanthan, Y., Kapilan, R. and Vasantharuba, S. (2018). Production and optimization of bioethanol from sour Orange (Citrus aurantium) peel using baker's yeast, Proceedings of 
the Jaffna University International Research conference (JUICE). (3)143.

Tamilarasan Suganya, N., Gandhi, S, Renganathan. K. (2013). Production of algal biodiesel from marine macro algae Enteromorpha compressa by two step process: optimization and kinetic study. Bioresource technology, 392400.

Tan, K. T. and Ang, G. T. (2019). Advanced Bioprocessing for Alternative Fuels, Biobased Chemicals, and Bioproducts Technologies and Approaches for Scale-Up and Commercialization, Woodhead Publishing Series in Energy, Chapter 8, 153-164.

Tania Sharmin.C.Md.Monirul Hasan, S.Aftabuddin,Md.Atiar Rahman, and Mala Khan. (2016). Growth, Fatty acid, and Lipid composition of Marine microalgae Skeletonemaa costatum availablke in Bangladesh cost:consideration as biodiesel feedstock. Marine biology, 1-8.

Teresa M.Mata, Antonio A,Martins,Nidia.S.Caetano. (2010). Microalgae for biodieselproduction and other appilications. Renewable and sustainable energy reviews, 217-232.

Tiwari, S., Arnold, R., Saxena, A., Singh, P. Patak, N., and Tiw, A.S. (2013). Optimization of transesterification process for biodiesel production from waste oil.Pharmacy and life sciences, 976-7126.

Turner E.C., Foster W.A. (2008). Oil palm on arthropod abundance and biomass in Sabah,Malaysia. Tropical ecology, 3 .

Vasudeven, P.T. and Briggs, M. (2008). Biodiesel production -current state of the art and challenges. Microbial biotechnology, 35:421-430.

Wang, Yue. (2013). Microalgae as third generation fuel: production, usage, challenges and prospects. 4-27.

Win, S. S. Trabold, T. A. (2018). Sustainable Waste-toEnergy Technologies: Transesterification, Sustainable Food Waste-To-energy Systems, Academic Press, 89-109.

XieW, Huang.X, Li..H, (2007). Soybean oil methyl esters preparation using $\mathrm{NaX}$ zeolites loaded with $\mathrm{KOH}$ as a heterogeneous catalys. Bioresour Technology, 98:936-9

Yihe Gao, Chapin Gregor,Yuanjie Liang,Dawei Tang ,Caitlin Tweed. (2012). Algae biodiesel- a feasibility report. Chemistry cental, 2-16.

Yoo, G., Park, W.-K., Kim, C.W., Choi, Y.-E., and Yang, J.W. (2012) Direct lipid extraction from wet Chlamydomonas reinhardtii biomass using osmotic shock. Bioresource Technology, 123: 717-22.
Yves Samyn, Didier vandenspiegal, Jerome degreef. (2009). SriLankan seaweeds methodologies and field guide to dominant species.

Zhu, Liandong. (2014). Sustainable Biodiesel production from microalgae cultivated with piggery waste water. 18-32. 